Emil Stanula

\title{
St. Hilary Of Poitiers On The Christocentrism Of The Spiritual Interpretation Of The Holy Scriptures*
}

\section{Introduction}

There was a period in the history of the Church, when the Holy Bible was not available for all the faithful ${ }^{1}$. Today, reading the Holy Bible is not only recommended in ecclesiastical teaching, but ordered in the confessional as one of the forms of the works of penance. This is a paradox both with regard to prohibition and to the command.

It is difficult to understand that reading God's letter - as the Holy Bible ${ }^{2}$ was called - addressed to every person could be banned or ordered.

There is no doubt that the sacred text is, on the one hand, a historical book, on the other a "holy book," and for this reason requires interpretation. Today in various congregations of the ordinary faithful, the Scriptures are explained not only for private but also public reasons because it is carried out at liturgical or paraliturgical meetings. The question arises both about the value of exegesis practiced by all the faithful, as well as about their right and objective competence to interpret the Holy Scriptures.

One can also look for answers to this question in the writings of the patristic writers. If one had sought for answer in the writings of Saint Hilary of Poitiers, it is not only because he is representative and witness of the tradition of the whole Church, both the ancient East and the West, but mainly because

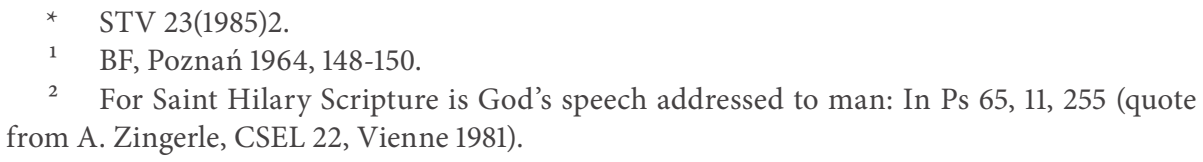


immediately after his conversion, being still almost an ordinary member of the faithful, he wrote "Commentary on the Gospel of Saint Matthew."

Undoubtedly, like other patristic exegetes, Saint Hilary was better prepared to comment on the Holy Scriptures than any contemporary believer, even one with great erudition. The erudition of Saint Hilary and people of his ilk was enormous ${ }^{3}$ but it is significant that erudition was something which was concealed by him, treated as something embarrassing. He himself admitted that it was because it made him concentrate for too long on the external aspect of the Scriptures.

The entire historical-cultural aspect of the Holy Bible was the subject of a deep study of the Fathers of the Church - so they may also be regarded as the fathers of modern biblical scholars. However, by emphasizing this aspect of the exegetical work of the Fathers of the Church, one cannot fail to notice that all their interest in the Bible was aimed at focusing on its spiritual meaning. One can see this kind of aspiration in the writings of Saint Hilary, not only in his exegetical writings, but also in polemical-historical and dogmatic writings. Athanasius of the West, as Saint Hilary is usually called, does nothing else in his theological activity than reading the spiritual meaning of the sacred text. Hilary, in spite of allegorism, subjectivism, randomness and the associative method of reading the spiritual sense of the Scriptures, remains the Father of the Church, and the Church has recognized this sense as its own.

One may, however, pose the question of 'on what basis'? What elements were crucial that Hilary, who was brought up in classical culture, living only a dozen years in the age of Christianity, despite his subjective methods of interpretation of the Holy Scriptures, became the Church's interpreter of the holy text, a witness to tradition, and therefore one can also ask what elements - when it comes to modern believers - determine that their reading of the sacred text can be fruitful even if they do not have great biblical erudition? The answer to the question posed seems to be found in several statements of Saint Hilary, which will be now the subject of our reflection.

3 It is enough to refer to Origen, Eusebius of Caesarea, and from the West: Saint Jerome, Saint Augustine.

4 According to Saint Hilary Scripture did indeed arise in a specific historical and cultural reality (he appreciates the value of studying historical and philological realities, he emphasizes the importance of erudition, knows different interpretations of a given fragment of the sacred text), but its meaning lies in the current influence of the holy text on the faithful: In Ps 126, 6, 617; cf. 119, 4, 546; 118, He 16, 409; Zain 1, 418;121, 3, 572; 121, 11, 577; 126, 12, 621; 132, 3, 686. 
[3] St. Hilary Of Poitiers On The Christocentrism Of The Spiritual Interpretation Of The Holy Scriptures

\section{Christ as Object, Subject and Interpreter of Holy Scriptures}

The first statement of the great importance of Saint Hilary is put in the following way: "The whole work, which constitutes the Holy Scriptures, announces with words, manifests through events, sets forth by the examples the advent of our Lord Jesus Christ." ${ }^{5}$ This is the basic theorem of the Bishop of Poitiers, included in the preface of the first textbook of typological exegesis, as the "Tractatus mysteriorum" is usually called.

\section{Scriptures Speak only about Christ}

The quoted statement appearing in various wordings and styles on the pages of the exegetical writings of the Bishop of Poitiers and introduce the distinction between "work" (opus) and sacred books, while the term "work" does not mean only the idea, the thought that is contained in Holy Scriptures, but something that can be expressed in words and through the historical events, and what can be realized in the form of an example.

By studying the contexts in which the word "work" appears, it is easy to see that, according to Saint Hilary, three aspects of meaning can be assigned: the effect of one's actions (the world, man is the work of God) ${ }^{6}$, then the action itself $^{7}$, and finally the action of a man in which the relation to God is expressed ${ }^{8}$. Considering the frequency of appearance of above-mentioned meanings, the last one deserves special attention.

In the writings of Saint Hilary the expression "work of law" appears most often, however, one should consider it not as an act of observing the law, but as an action in which the relation of people appears, especially Old Testament characters towards Christ. The law in this expression does not mean the moral or ritual law, but, first and foremost, the "prophecy." The law announces the coming of Jesus Christ, His incarnation, life and activity, passion, death and resurrection, and finally the $\mathrm{Church}^{10}$. According to the definition of Saint Hilary, following Saint Paul, the law is the "shadow of the future," the "shadow

5 TM 1, 1, 72 (I quote here the edition of J. Brisson, SCh 19 bis, Paris 1967).

6 E.g. In Mt 8, 5, I, 198 (I quote the edition of J. Doignon, Sch 254, T. I, Paris 1978 and SCh 258, T. II, Paris 1979); In Ps 91, 8, 351.

7 In Mt 16, 9, 56; In Ps 62, 7, 220.

8 In Mt 4, 13, I, 130/132; In Ps 120, U , 566/567; 120, 6, 583; 124, 8-9, 603.

9 In Mt 24, 1-2, 164/166.

10 In Mt 4, 14, I, 132; cf. 4, 1, I, 120; 4, 15-16, I, 134. 
of spiritual things," the shadow cast by the "body" of the New Testament reality $^{11}$. The "work of law" finds its completion and fulfillment in Christ. Even in the few statements in which the law is considered moral (it was a guarantor of discipline, purity, it developed moral habits and habits of honest behavior), it was aimed at strengthening faith in what was to come; it was to lead to the reality that was expected and awaited; The law was valuable insofar as the person observing it took into account its intentional or - to use the language of the Bishop of Poitiers - a "meditative" or "pedagogical" nature ${ }^{12}$.

Following the tradition, in many cases, Saint Hilary identifies the "law" with the history of all Israel and all the books of the Old Testament ${ }^{13}$. It results from the belief assuming the work of law, which is concretized in the history of a particular individual and the chosen people, and which concretization is described in the sacred text. In this concretization a special role is played by prophets, whose first obligation was to announce the coming of Jesus Christ and all his mystery realized in a concrete historical, ecclesiological, mystical and eschatological reality ${ }^{14}$; then calling for the observance of meditative and pedagogical law ${ }^{15}$; and finally, the obligation to make the first interpretation of the history of Israel, the concretization of the "work of law," extracting from it events that clearly heralded the advent of Christ ${ }^{16}$. The Old Testament events could be then regarded as a concrete relation of people to the law; people who have accepted its meditative and pedagogical dimension, or treated it only as a set of provisions, and therefore prohibitions and commands ordering and regulating human life.

Prophets, pointing to the meditative character of law, on the one hand fulfilled the "work of law,"17 on the other, they made the first interpretation of history in the perspective of the Christological reality of the law, that is, they announced the coming of Christ ${ }^{18}$. Perfectly understanding the meditative

11 In Ps 118, Aleph 5, 361/362; Beth 8, 374; cf. In Ps 91, 1, 345.

12 In Ps 118, Mem 10, 471; In Mt 17, 11, II, 70; cf. In Ps 91, 1, 345; 118, Daleth 5, 393; Lamech 11, 463; In Mt 18, 3, II, 78; 20, 5, II,. 106; 24, 6, II, 170.

13 In Ps 118, Aleph 5, 361/362; cf. B. de Margerie, Introduction à l'histoire de l'exégèse. Les pères grecs et orientaux, Paris 1980, 39-45.,

${ }_{14}$ In Mt 11, 2, I, 252; 23, 7, II, 160; In Ps 67, 32, 307; 68, 24, 344; 126, 15, 623; 138, 12, 753; TM $1,12.96 ; 1,27,120 ; 1,29.122 ; 1.32,126$.

15 In Mt 2, 4, I, 106; In Ps 67, 32, 307; 118, Daleth 5, 393; Vau 1, 418;. 128, 1, 637/638; 142, 2 , $805 ; 146,7,849$.

16 In Ps 134, 1, 695; 134, 6, 697; 134, 18, 705; 134, 20, 706; 134, 21, 707; TM 1, 32, 126.

17 In Mt 11, 2, I, 252/253; In Ps 52, 3, 119; 67, 1, 276; 141, 3, 801.

18 TM 1, 29, 122; In Ps 134, 1, 695; 134, 6, 697; In Mt 4, 14, I, 132; 7, 2, I, 180. 
[5] St. Hilary Of Poitiers On The Christocentrism Of The Spiritual Interpretation Of The Holy Scriptures

nature of the law, interpreting the specific works of law under the influence of the prophetic spirit, they showed some examples by which they strengthened faith in those features of Christ which he manifested himself upon his coming to earth ${ }^{19}$.

\section{Christ as Creator of Reality Described in Holy Bible}

Saint Hilary, claiming that the "whole work," which constituted the "holy books" speaks only of Christ, adds an important remark: "For all this time of the created world, Christ gives birth to the Church, he sanctifies it, washes its guilt away, he chooses it, separates and redeems it, that is, through Adam's dream, the flood of Noah's time, the Melchizedek blessing, the justification of Abraham, the birth of Isaac, the captivity of Jacob, through true and understandable images in the patriarchs." ${ }^{20}$ Developing this thesis concerning Christ, the creator of the "work" expressed in the sacred books, the Bishop of Poitiers cites several examples. Prophetic words from the Book of Genesis: "This is the bone of my bones and the flesh of my flesh," according to Saint Hilary, are pronounced by Christ with the lips of $\mathrm{Adam}^{21}$; when interpreting the creation of Eve Hilary notes that Christ, the creator of man and woman, announces through their creation the task which he fulfilled himself, when the Word became flesh and the church became the body of Christ. The Church, which was born and was called into existence through the blood and water flowing from His side, is still the body through which the eternal Word, the Son of God, abides in $\mathrm{us}^{22}$.

Then, referring to the story of Eve, he presented the history of the Church. By bearing children and bringing them up in a spirit of fidelity to Christ, the Church, made up of sinners and pagans, alone being burdened with guilt, like Eve, will be saved, resurrected in a bodily sense in eschatological times ${ }^{23}$. In order to summarize the examples given, Saint Hilary states: "The mystery which is concealed in Adam and Eve announces the coming of Christ and the Church: at the beginning of history all this has been accomplished through the creation of Adam and Eve, what Christ prepared for the Church at the end of history." ${ }^{24}$ Christ is, according to Saint Hilary, not only the creator of the 
whole reality described in the Bible, but also the pattern by which this reality came into being. Thus the New Testament reality turns out to be a reality that imitates the reality of Old Testament, which existed earlier.

This kind of reversal of the order in which what follows is imitated by what is happening earlier is proof of the great "divine mercy," which consists in the fact that what had to be fulfilled in God had been earlier the subject of imitation. What was fulfilled in him and what he fulfilled himself was announced by types, historical circumstances and entire generations starting from $\mathrm{Adam}^{25}$.

The thesis, according to which, the object reproduced and imitated appeared later than its reproduction, imitation or reflection, and the fact that reproduction, reflection are so accurate and precise that it is difficult to distinguish them from the object reproduced, that one can even speak of the "first copy," is justified by Saint Hilary by means of the statement that God reveals only those things, with regard to which he decided that they should be first the subject of reflection and meditation, that before they become a fact for people, they were noticed in individual stages of the development of human life, and in their customs and were the result of human activities ${ }^{26}$.

\section{Christ as Interpreter of Biblical Reality}

St. Hilary refers a Christological biblical reality, the creator and model of which is considered Christ, to a deep conviction about Christ as an interpreter of this reality. The Bishop of Poitiers states explicitly that, until the coming of Christ, the Holy Scriptures remained "a closed and sealed book," a "useless book" for $\operatorname{man}^{27}$. It was only the mystery of Christ that became the "key," the "lion of the tribe of Judah" who broke the "seven seals" through incarnation, passion, death, resurrection, glory, kingdom and judgment. The principle of the "key" includes not only those who lived before but also those living after the coming of Christ. Like the prophets, so the apostles in Christ find the "key" to break the "seal" of the mystery, the Holy Scriptures, as Christ himself confirms after the resurrection, namely that only $\mathrm{He}$ is the authoritative interpreter of the sacred text ${ }^{28}$.

Saint Hilary states the same assertion more generally when he says: "Do not doubt that what the Psalms say should be understood according to the

25 TM 2, 5, 150; 1, 27, 120; 1, 32, 126.

26 TM 1, 32, 126.

27 Instr. Ps 5, 6/7

28 Instr. Ps 6, 7/8. 
evangelical preaching." ${ }^{29}$ The last statement finds its full explanation in the exegetical practice of the patristic writers. In order to understand what the prophet, the psalmist, or the hagiographer of the books of the Old Testament wanted to say, one should first ask Christ, his apostles, because the Gospel writings and the apostles speak about the same thing that the Old Testament did. This practice is expressed in countless New Testament quotes when explaining the meaning of the texts of the Old Testament. It is also implied by the definition of exegesis as a "comparison" of Old Testament and New Testament events, and the latter with Church events ${ }^{30}$. But St. Hilary also goes the other way around. He claims that in order to understand what Christ, and his apostles, said or did, as well as what is currently happening in the Church, one should seek clarification in the writings of the prophets, in the history of Israel, in the experiences of people who awaited the arrival of Christ in Old Testament times ${ }^{31}$.

If one would like to answer the question of how Christ explained the Holy Scriptures, it would be necessary to read all the writings of Saint Hilary that say that Christ is the one who - through birth, life, activity, death, resurrection, the Church - fulfills all that he has initiated - in the form of an announcement, or in the form of implementation - in both the Old and the New Testament.

\section{History of Salvation}

Three statements of Saint Hilary about Christ as the only reality of which the Holy Scriptures speak, then of Christ as the creator and model of this reality, and finally of Christ as the interpreter of this reality find their further explanation in the concept of the history of salvation. From the point of view of the interpretation of the Holy Scriptures, it should be said that if Christocentrism is considered in the writings of Saint Hilary's as basic presupposition of every exegetical work on the Scriptures, then the history of salvation authorizes every participant, that is, every person to the exegetical work itself.

29 Instr. Ps 5, 6.

30 Instr. Ps 5, 6; definition of exegesis TM 1, 1, 72.

31 The following list illustrates the predictions for quotations: Mt quotes the Old Testament 32 times and the New Testament 33 times; Ps quotes the Old Testament 765 times and the New Testament 1180 times; TM quotes the Old Testament 47 times and the New Testament 57 times. 


\section{First Adam}

In order to present a synthetical view of the essential features of the concept of the history of salvation according to St. Hilary, the following elements should be mentioned.

All mankind can be derived from two Adams: earthly Adam and heavenly Adam. The first one, because of his origin, was called "the son of God." As a result of a double blessing, he was granted a dual task: to provide the earth with his offspring and to develop in himself and in his offspring the doctrine of God. Both tasks remain inseparable and equivalent, and both tasks granted man a status of a king and a priest ${ }^{32}$. As long as Adam remained the father of all mankind, he was the king and priest of all creation. Yet when considering Adam idealistically, as representative of whole human race, Saint Hilary often refers to his royal and priestly dignity.

Adam was the "favorite of God," the most wonderful of God's works. This dignity is emphasized by the threefold creative act: first, the creation of the soul according to the "image and likeness" to Christ; then the creation of the earthly body in the image of the earthly creation; and finally the connection of the soul with the body by the special and powerful breath of the Spirit. Human dignity is emphasized by its essence, nature which is the synthesis of what is earthly, with what is heaven, as well as free will and the right to decide about oneself, and finally being assigned a task of exercising royal and priestly power over all creation $^{33}$.

Adam was not only a king, but also a priest. He was supposed to spread the knowledge of God in the created world through which he was to unite the human race and all material beings with God. Endowed with reason, the gift of judging and discerning good and evil, he had the ability to become aware of the image and likeness of God in him. If he developed the received gifts, he would become "useful" to himself and the whole of creation, he would recognize the "image" of the one he was a reproduction of, he would have achieved similarity, and in the priestly function he would worship God not only in his own but also in the name of the world of the whole visible creation, of whom he was a king ${ }^{34}$.

32 In Mt 1,1 , I, 90; In Ps 66, 2, 270; TM 1, 1-2, 74/76.

33 In Ps 118, Jod 6, 442; cf. 118, Jod 1, 439./440; 129, 4, 650.

34 In Ps 65, 4-6, 251/252; 65, 2, 270; 129, 5, 651; 134, 14, 702; cf. 52, 8, 122; TM 1, 1, 74. 
[9] St. Hilary Of Poitiers On The Christocentrism Of The Spiritual Interpretation Of The Holy Scriptures

\section{Second Adam}

The first Adam, however, did not fulfill the priestly act, and thus also lost his royal dignity. He refused to worship God, rejected his right to possess the kingdom, broke the covenant with God, lost his paradise, destroyed order and harmony in himself and in all material creation, he took the attitude of a slave, became a master of disorder, lost his nobility and blessed spiritual growth, dishonored the name of man, and became like an animal; he ceased to be known to God, worthy of God's love, his will was weakened, his knowledge became limited, he lost the privilege of being the "head" of the human race, the patriarchal king and priest. Hilary, however, was not a pessimist. He saw in the divine revelation that the image of divine mercy manifested itself over the misery of mankind. This mercy was manifested at the moment of Adam's fall and it saved the human race. In the eternal plan of God the Father, there was another Adam, the savior of the first Adam according to which the first one was created ${ }^{35}$.

In comparison with the first, the second Adam is heavenly in his nature. His body possesses the properties of our body, but because he comes from the Virgin Mary, he is conceived by the power of the Holy Spirit, he can be considered a heavenly body. The soul in Christ has not been changed, but it has become heavenly through unity with the Word of God. Through the unity of the Word with the soul and the body, there is such a close unity in Christ that according to the doctrine of the Catholic Church we speak of the unity of man, David, Jesus, or the "new Creation."36

By being born of the Virgin, the second Adam gives a new beginning to humanity, takes over the "blessing" of the first Adam, becomes the father and head of all mankind, the king and priest of creation ${ }^{37}$. By accepting this form of submission, and death as a sacrifice, a form of devotion to God, through this priestly act he again provides the human race with gift of eternity, sanctifies it and frees it from the burden of sin, he unites people with God, with each other and with all creation. He becomes a High Priest, mediator in the act of knowing God, a teacher, a doctor, a father ${ }^{38}$. As a consequence of the priesthood act completed, Christ restores royal dignity to man, being the king and the center of human and

35 In Ps 118, Iod 2, 440; 136, 5-7, 726/728; 142, 6, 807/808; In Iob 1, PI 10, 127 B; cf. In Ps 13, $1,80 / 81 ; 66,2,270 / 271 ; 142,6,608 ; 149,3,867 / 868$.

36 The following authors discuss the issue of Christology: A. Orioff, La Christologie d'Hilaire de Poitiers en relation avec une description des doctrines christologique du II au IV, Moscow 1909; P. Galtier, Saint Hilaire de Poitiers, Le premier docteur de l'Eglise Latine, Paris 1960, 108-158.

37 In Ps 67, 22, 287; T M 1, 18, 116.

38 In Ps 68, 23, 333; 91, 9, 353; In Mt 4, 1, I, 120; 3, 6, I, 116; 14, 16, II, 30; T M 1, 18, 116; In Ps 66, 9,$275 ; 149,3,867 / 868$. 
world history, he allows all those who accept him in faith to participate in his power. Those who believe in Christ receive the gift of being children of God, the eternal inheritance of the kingdom, the church, the body of Christ, the city of the great king, the "royal priesthood."

\section{History of Man as History of Christ}

Saint Hilary often repeats that knowing and understanding the history of the human race leads to an understanding of Christ, the Church, that every detail of history if it does not contribute to education in the spirit of Christ and the Church will be tantamount to distortion and perversion of their ideas. The entire task of members of the Catholic Church is recognized by our author in striving to involve everyone in a conscious participation in the history of the second Adam and his kingdom. He uses every opportunity to show that the history of the Church has been entrusted to the apostles and their successors. He explicitly states that the Lord's power and strength were given to the apostles, who became a "reflection of the Lord, the 'heavenly', With the Lord's power, they purify what the first Adam has polluted, fulfill the function of Christ's eyes, are the light of the world, the lamps of God, the transmitters of the mysteries of Christ. Bishops and presbyters are the successors of the apostles, heirs of truth and the heavenly forces of the second Adam, distributors of divine gifts, princes and fathers of families of mankind ${ }^{40}$.

Beginning with the history of salvation, Saint Hilary considers his main task as a bishop, pastor and spiritual father to familiarize his faithful with the history of salvation, to make them aware that spiritual life is nothing but a history in which and through which an ever closer union with Christ is achieved.

In the life of individual believers and their groups or entire nations there is no coincidence, randomness, fate determined by movement of stars, but a divine pedagogy aimed at forming appropriate members for the body of Christ. Teaching the faithful to read the history of their own specific life in the ecclesial community in the Scriptures, which is tantamount to a communion with Christ, constitutes an important task of Hilary as an exegete, a theologian and the Father of the $\mathrm{Church}^{41}$.

39 In Ps 149, 3, 867; cf. In Ps 2, 32, 60; 51, 3, 98; 138, 1, 744; 138, 29, 764; In Mt 1, 1, I, 90.

40 In Mt 6, 1-4, I, 170/174; 12, 15, I, 280; 27, 1, II, 202; In Ps 138, 34-37, 767/771; De Syn 9, PI 10, 546 A; In Ps 67, 12-13, 287/288; 118, Nun 2-3, 475; 138, 34, 767.

${ }^{41}$ For Saint Hilary's mystery of Christ is both a historical fact (the historical Christ) and a presently realizing history of salvation (the mystical Christ). For this reason, Hilary juxtaposes biblical events with the events concerning an individual man: in Ps 13, 4, 81/82; TM 1, 1, 72. 
[11] St. Hilary Of Poitiers On The Christocentrism Of The Spiritual Interpretation Of The Holy Scriptures

\section{Exegetical and Theological Consequences of Biblical Christocentrism}

Biblical Christocentrism and the history of salvation imply specific norms for fruitful reading and spiritual understanding of the Holy Scriptures, and thus for practicing theology.

\section{Essence of Spiritual Sense of Holy Bible}

However St. Hilary explicitly states that the "whole work" which constitutes the Scriptures must be referred to Christ, but also repeatedly admits that whenever the holy text speaks of Christ, it often refers to a detail which clearly indicates only Christ. What is more, in several cases, he even fights unjustified biblical Christocentrism $^{42}$.

In order to answer this difficulty, it is first necessary to pay attention to those statements in which Saint Hilary emphasizes the way of speaking of Christ. By opposing those who referred Psalm 120 to Christ, the Bishop of Poitiers claims that it does not refer directly to Christ. Psalm 120 speaks of divine revelation, the source of the theory and practice of human life, especially faith in divine promises, passed on to man. The commentary on Psalm 120 imposes two general remarks: the claim that the Scriptures speak only of Christ is to be understood explicitly or implicitly. Often the mystery of Christ is in first place, and in other cases the other truths of divine revelation are considered of highest importance ${ }^{43}$.

Commenting on Psalm 138, Saint Hilary states that the content of the Holy Scriptures should be referred to Christ even when it directly describes the life of patriarchs, prophets, martyrs, apostles, heathens, Jews, because "everything in Christ and through Christ came into being," therefore what was said about other people or events should be actually referred to Christ, in "which and through whom everything" has been realized. Our author deduces the following conclusion from the aforementioned theorem: I present this kind of explanation in order that nobody should think that "everything that is said in the Psalms cannot be - without justification - referred to Christ." Most often Saint Hilary finds this justification in the letters of St. Paul ${ }^{44}$.

42 In Ps 1, 2, 20; T M 2, 11, 156/158; cf. In Ps 63, 3, 226; 141, 3, 801.

43 In Ps 120, 1-4, 561; cf. 1, 3, 21; 63, 2, 225; 118, Gimel 7, 381; 120, 10, 565; 135, 2, 713; 136, 2 , $745 ; 138,5,748 ; 139,2,777$.

44 In Ps 138, 1, 744. 
Undoubtedly, the specific logic and unique coherence of the argument of the Saint Hilary can amaze the modern reader of the treaty on the $51^{\text {st }}$ Psalm. From the very beginning to its last parts, the treaty indicates that Jews, despite being a chosen people, despite God's miraculous intervention in their specific history, always keep the same infidelity and hatred for Christ, with which they addressed God in the course of their history. This unfaithfulness finds its culmination when they crucify Christ. A question arises about the motives of blurring the distinction between the subsequent stages of the history of Israel by Saint Hilary. Does the crucifixion of Christ have the same qualification of guilt and punishment for unfaithfulness and malice in the case of Jews both before and after the coming of Christ?

In order to solve this difficulty, it should be remembered that Christ occupies a central place in all the writings of Saint Hilary. To confirm this truth, the Bishop of Poitiers uses the methods of Scripture interpretation typical of the spirit of that era, such as love for etymology, the symbolism of numbers, the search for nuances and difficulties in the literal meaning of the holy text, etc. An example is the treaty on the $51^{\text {st }}$ Psalm. After presenting the methodological remarks, the author introduces the etymology of the name Abimelech, which means "the house of brother's power." This etymology reminds Saint Hilary of the words of St. Peter: "You as living stones will be built into a spiritual temple into a holy priesthood" (1P 2:5); "But you are a chosen generation, a royal priesthood, an holy nation, a peculiar people" (1P 2:9). After creating the semantic bridge between the text of the Old and New Testaments through the etymology and quotations of the New Testament, Hilary states: "This very house of Abimelech, that is the home of the brotherly kingdom, was entered by the real David, the holy king, the righteous, the East, because he became a man. Humankind is his brotherly home, the brotherly kingdom, because mankind is co-successor of the same body, glorious body, according to the words of Christ himself: 'Come, be blessed of my Father, possess the kingdom which has been prepared for you even since the creation of the world.' (Mt 25, 34)." The whole argument ends with the following conclusion: "The Word that has become flesh dwells in us, who are both brothers and a spiritual home and a royal priesthood." 45 or, to express this idea in modern language one can say that "the home of the brotherly kingdom" is nothing but the history of the salvation of fallen humanity, or, in the language of Saint Hilary: the mystery of the eternal plan, the mystery of the will of God and the blessed kingdom, the mystery of the father's will, the mystery of human salvation; since the creation of the world, the mystery of our 
[13] St. Hilary Of Poitiers On The Christocentrism Of The Spiritual Interpretation Of The Holy Scriptures

salvation has been manifested in Christ." ${ }^{46}$ The entire treaty on the $51^{\text {st }}$ Psalm presents the development and implementation of the history of the salvation of mankind, first in the context of consequences of incarnation for all people, then the relation of the people chosen to it, both before and after it has been completed, and the vocation of all mankind to participate in $i^{47}$.

A similar thought pattern can be found in many places of the Treaties on the Psalms. There is a constant tendency in the writings of Saint Hilary to organize and systematize all biblical material according to the main idea taken from Saint Paul that Christ is at the center of the history of mankind. Saint Hilary recognizes this idea in an interpreted text either directly or indirectly (he often suspects it or assumes it). Using the idea taken from Saint Paul, he combines and integrates all the elements of the meaning directly or indirectly resulting from the interpreted text, that in his comments one and logically coherent historical-conception reality is created (despite the fact that particular elements of this reality, taken in themselves, in other context, could provide material for a different thought structure). The reality created by Hilary is nothing more than a consistent elaboration of the thesis and assumption that the "whole work" of the Holy Scriptures is of a Christological nature. Even if this reality does not appear explicite in the psalmist's statements or in the narrative of biblical events and it does not directly speak about Christ, it is even present in a more natural way in the broader historical context. Putting the same thought in the terminology of biblical patristic meanings, it must be said that - according to Saint Hilary and other patristic writers - there is only one biblical sense and one subject of theological studies, which is the mystery of Christ, considered from various aspects and deepened over the centuries, in the view of the impossibility of certain authors of achieving its complete knowledge.

\section{Faith as Condition of Participation and Understanding historic-soteriological Reality of Holy Scriptures}

The basic norm of practicing exegesis and theology follows from a biblical historic-soteriological reality concentrated in Christ. The most basic condition, without which one cannot talk about an exegist or a theologian (according

46 L. Małunowiczówna, De voce sacramenti apud S. Hilarium Pictaviensem, Lublin 1956, 134-150.

47 In Mt 2, 5, I, 108; 17, 9, II, 70; 18, 3, II, 78; 20, 8, II, 1110; 28, 2, II, 218; 31, 7, II, 234; In Ps 2, 43,$70 ; 51,16,108 ; 53,3,136 ; 53,6,151 ; 54,13,156 ; 56,5,171 ; 58,9,187 ; 61,2,209 ; 67,23,298 ; 68$, 13,$323 ; 131,4,664 ; 138,2,745 ; 139,2,778$. 
to Saint Hilary) is a norm of faith. Its necessity is justified by the Bishop of Poitiers on many levels.

From an anthropological perspective Saint Hilary regards faith as the main factor in the realization of man. Man was supposed to, and is still supposed, to become himself. Having belief in divine promises was a decisive condition of whether a man would become a spiritual being, who is useful not only for himself, but also for other creatures. Above all, will man fulfill the purpose of being called into existence, that is realizing the "image" and "likeness" to Christ dependent on faith. Admitting the first betrayal of God, by advocating external values, he committed an act of unbelief, which became the mother of his soul, and sin has become the father of his body. An inner man, called to reproduce and realize the image of Christ with his will, abandoned his task and vocation, realizes the external image, and consequently adopts bodily properties ${ }^{48}$.

A return to the original state of man is possible only through faith in Christ. Faith in Christ makes man return to the original state, makes him regain the possibility of realizing the ideal of man and of all mankind. Faith in Christ unites all people and all of mankind with God. Faith, which has its beginning in the will, unites in man the spiritual element with the material, unites the human aspect with the divine into one inseparable whole. For this reason, faith in the mystery of the incarnation is paid special attention in the writings of the Saint Hilary ${ }^{49}$.

Intellectual preparation is absolutely necessary for a fruitful reading of the Holy Bible. Scripture, however, is mainly a "speech of God" (sermo divinus), which is why it can only be understood through faith in Christ and the gifts of the Holy Spirit. Faith and gifts distinguish the exegete not only from educated people and experts in various disciplines, but even from those experienced

48 In Ps 52, 8, 122; 54, 8, 152; 1,18, Jod 1, 439; Nun 20, 486; Ain 14, 503; 144, 2, 829; Is Mt 10, 18-20, I, 236/240; 10, 22-23, I, 240/242; De Trin. 10, 1, PL 10, 345 A. Faith according to Saint Hilary is understood as: 1) fit quod dicitur, which is synonymous with veritas: In Mt 10, 29, I, 250; 18, 7, II, 114; In Ps 64, 1, 233; 118, Phe 4, 508; TM 1, 37., 134; 2) rerum fides that is, the veracity of historical events: In Mt 1, 2, I, 92; 2, 2, I, 102; 3, 6, I, 120; 7, 1, I, 180; 14, 14, II, 28; 16, 1, IX, 48; 17, 3,' II, 64; 19, 2, II, 92; In Ps 1, 21, 112; 1, 29, 122; 1, 31, 126; 51, 2, 97; 68, 12, 322; 146, .1, 844; TM $1,3,78 ; 3)$ fides dictorum - the veracity of prophetic promises: In Mt 5, 12, I, 104; 11, 2, I, 254; 11, 11, I, 266; 21, 1, II, 122; 30, 3, II, 224; In Ps 2, 44, 71; 66, 19, 239/240; 90, 1, 345; 4) fulfillment of prophecies: In Mt 30, 8, II, 223; 32, 6, II, 246; In Ps 53, 3, 136; 119, 3, 546; 134, 6, 698; TM 1, 6, $86 ; 1,8,90$.

49 In Ps 118, Ain 14, 503; Nun 20, 486; In Mt 7, 6 I, 184; 10, I, 218; 14, 17, II, 30; 15, 4, II, 38; 17 , 3. II, 63; cf. In Ps 52, 9, 123; 67, 286; 67, 12, 287; 67, 28, '3104; 118, Phe 4, 508; 138, 34, 767, 138, 38, 772 . 
[15] St. Hilary Of Poitiers On The Christocentrism Of The Spiritual Interpretation Of The Holy Scriptures

Jewish exegetes who were brought up and gained education by studying the holy text.

Due to its essence, faith becomes a condition without which one cannot speak of exegesis and the theologian. This conviction of Saint Hilary is a consequence of biblical Christocentrism, the concept of man as the image of Christ; it is Christ, through the incarnation, who restores the original appearance to man. Faith in the present state of being introduces man into the Christological reality. The exegete, by participating in this reality, does not have to concern himself with chronology, literary genre, various authors, because in all books one and the same word of God is expressed. From this point of view, faith justifies the principle of the Old Testament's interpretation of the Holy Scriptures in the context of the New Testament, the interpretation of the New Testament in the context of the Church, and the interpretation of the Church in the light of Christ and His eschatological kingdom. One and the same faith in Christ merges all the biblical books, creates a homogeneous environment in which the mystery of Christ is either announced or realized, or is intended to be completely fulfilled in the eschatological kingdom ${ }^{50}$.

Finally, the fact that the Scriptures use specific biblical language can be considered as an argument in favor of faith. St. Hilary accepts the conventional character of the meanings of the individual elements of the language. Each element: words, characters of language are assigned by interlocutors with a certain meaning. Assuming the conventionality of meanings, the interlocutors understand each other thanks to the ties existing between them, which are based on shared experience, customs, belonging to one and the same cultural and spiritual group ${ }^{51}$.

The specific language of the Holy Scriptures could not be comprehensible and useful to man, if one would not consider Christ as "key," a reference point necessary for understanding the conventional meanings of its elements. Prophets, believing in the advent of Christ, understood this language. Seventy translators, in the community of Jewish believers, translated the Hebrew text into Greek and carried out the first interpretation of the Scriptures ${ }^{52}$. On the other

50 In Mt 1, 4, I, 96; 1, 5, I, 98; 5, 15, I, 168; 23, 6, II, 158; In Ps 1, 7, 24; 61, 2, 209; 63, 5, 227; 63, 9, 230; 65, 7, 253; 67, 21, 295; 144, 4, 830; 148, 3, 861; cf. In, M t 13, 2, I, 296; 29, 2, II, 220; 31, 4, II, 230; 33, 4, II, 252; Instr. Ps 5, 6; In Ps 1, 9, 25; 2, 20-21, 52; 2, 33, 62; 54, 4, 99; 51, 16, 108; 91, 1, 345; 118, Jod 12, 446; Mem 4, 468; Phe 4, 508; 125, 2, 605.

51 This is demonstrated by his encouragement of his readers to undertake semantic analyzes of language elements.

52 Instr. Ps 8,9; In Ps 2,3,40. 
hand, those Jews who did not believe in the arrival of Christ, which was foretold by the prophets, deprived us of this "key," which is crucial for understanding Scriptures, rejected faith in the literal coming of Christ, rejected the possibility of knowing the Christological reality of the law, what is more, they separated themselves from the reality in which, as an environment of common religious experience, the experience of faith, the biblical language was understandable, communicative and functional ${ }^{53}$.

\section{Remaining in Continuous Communication with Christological Reality}

The second consequence for the exegete-theologian, resulting from the Biblical reality considered from the historic-soteriological perspective, concentrated in Christ, flows from faith. It is a necessity of continuing tradition, in connection with the Church, within the continuously developing history of salvation. Justifying the foundations of the authority of the Septuagint, the Bishop of Poitiers cites two arguments: the Septuagint was established before the coming of Christ, and the translators themselves had all the necessary competences to carry out their task ${ }^{54}$. The first argument suggests that seventy interpreters, according to the tradition of Moses, in whose faith the coming of Christ was maintained, made the first translation of the Holy Bible before the coming of Christ, and revealed the Christological reality through the competent interpretation. The second argument, justifying the competence of interpreters, indicates explicitly that the tradition and background valuing faith shaped their personalities, and at the same time educated them in the way they could become exegetes and theologians.

Being strongly embedded in tradition is tantamount to being strongly embedded in the Church. St. Hilary states that the Word of God has entered the boat of the Church, and this explains why only the one who is a member of the Church is able to understand the Word of God ${ }^{55}$. The necessity of staying in the community of the Church results from the necessity to remain in the Christological reality as an environment and context in which "divine speech" can be understood. The external sign of remaining in the Church is confirmed by appealing, by Saint Hilary, not to the authorities of ancient and modern theologians and exegetes but to the authority of the people of faith, seventy

54 In Ps 2, 3, 39/40.

55 In Mt 13, 1, I, 296; 7, 10, I, 190; 14, 9, II, 20 
[17] St. Hilary Of Poitiers On The Christocentrism Of The Spiritual Interpretation Of The Holy Scriptures

translators, prophets, and apostles. The apostles' authority is of key importance especially and has a decisive role in resolving all biblical problems ${ }^{56}$.

\section{Conclusion}

Two general remarks arise from the synthetic interpretation of the biblical christocentrism presented by Saint Hilary. The first concerns the subject of theological study and biblical studies. The above-mentioned presentation of the arguments of Hilary implies that the mystery of Christ manifesting itself in history, of which he is the creator and interpreter at the same time, constitutes the essence of theology and exegesis. The biblical senses, considered as the result of biblical and theological research and study, in this approach are nothing but different aspects of incomprehensible mystery of Christ. Because the mystery of Christ is revealed in history and is history itself, therefore the theological and exegetical study is of a historical nature at least in the sense that this mystery can be recognized by applying the aspect-oriented method by comparing what is contained in the Scriptures with what people are currently experiencing in a particular episode of history, because the creator of the latter is Christ. One could say that it seems to follow from the last statement, that for Saint Hilary, there are no rigid forms of dogmas established once and for all but one: the incomprehensible mystery of Christ. Although always and everywhere studied, it will never be understood and expressed in words. In the act of studying it, a person constantly extracts new aspects from it. It is the task of the exegete and theologian to update it, to make the faithful acquainted with the complexity of its message. If ordinary believers do this even at liturgical meetings, then, according to Hilary, even though they have not completed specialist theological and biblical studies, they can read and interpret the holy text fruitfully.

The second remark indicates the conditions sine qua non of the existence and operation of the theologian, exegete, no matter if he is a specialist or an ordinary faithful. These conditions are faith in Christ and perservance in participation in the Christological reality of the Church and the community of the faithful. The above claim does not undermine the value of biblical and theological studies - as understood by us in terms of erudite knowledge. Scholarly biblical commentaries and the theological and historical writings of Saint 
Hilary can be regarded as the denial of such a conclusion. The Bishop of Poitiers, by encouraging his readers - by his own example - to intellectual and moral preparation for the study of the Scriptures, also emphasizes the pointlessness of practicing exegesis and theology if it is not accompanied by faith in Christ, in isolation from tradition, the continuity of history, finally in isolation from the community of the members of Church. 